\title{
Different features of coeliac disease in two neighbouring countries
}

\author{
H Ascher, K Holm, B Kristiansson, M Mäki
}

\begin{abstract}
Against the background of reported different trends of incidence and presentation of coeliac disease in Sweden and Finland, a joint study was done to explore potential causes. The clinical study confirmed that classical symptoms and diagnosis before 2 years of age dominated in Sweden. In Finland, the symptoms were more diffuse and diagnosis in most cases was made after the age of 8 years. A significantly lower weight score attained at diagnosis was seen in Swedish patients compared with Finnish. No significant difference in HLA expression was found. Infant feeding was investigated by studying food records of healthy infants. Swedish infants ingested three times more wheat protein at 9 months and twice as much at 12 months compared with Finnish children.

It is concluded that the intake of infant cereal protein might influence when and how clinical coeliac disease appears. The question whether or not it is important for if coeliac disease will be acquired still remains to be answered.

(Arch Dis Child 1993; 69: 375-380)
\end{abstract}

Childhood coeliac disease seemed to have similar characteristics in Sweden and Finland around 1970. The incidence in both countries was estimated to be $0.5-1$ per 1000 live births, ${ }^{12}$ and the clinical presentation was the classical one with diarrhoea, low rate of weight gain, and malnutrition in children below the age of 2 years.

From the middle of the 1970 s, decreasing incidences were found in the $\mathrm{UK}^{3-6}$ and Ireland ${ }^{7}$ and later also in Austria. ${ }^{8}$ In a study from Italy, Greco et al reported an unchanged incidence with a predominance of classical cases. ${ }^{9}$ From Tampere, Finland, a change from the classical presentation to one with mild and atypical signs and symptoms presenting at school age and in adolescence was reported. ${ }^{110}$ This resulted in a cumulative incidence of 0.12 per 1000 at 2-3 years of age, reaching 1 per 1000 in adolescence.

Co: Dr Ascher.

Accepted 3 June 1993
On the other hand, during the 1980s, a threefold increase in incidence to levels around 3-3.5 per 1000 live births, one of the highest figures reported, was found in Sweden, with the classical presentation still predominating. ${ }^{11} 12$ This increase in incidence occurred during a period when feeding habits changed: breast feeding increased both in prevalence and duration, the introduction of gluten was delayed, and the amount of gluten consumed by infants possibly increased. ${ }^{13}$

The disparate trends of coeliac disease in Sweden and Finland prompted us to make a joint study with the aim of establishing data on the observed differences in clinical expression and age distribution, and exploring potential causes of these differences, such as genetic factors and feeding habits.

\section{Patients and methods}

\section{CLINICAL STUDY GROUPS}

Cases of coeliac disease diagnosed between 1 January 1985 and 31 December 1989 in the paediatric departments in Tampere, Finland (Finnish patients) and Gothenburg, Sweden (Swedish patients) were included in the study (table 1). Patients presenting with dermatitis herpetiformis were excluded. In Gothenburg only children born within the city of Gothenburg were included. The diagnosis was made according to the European Society for Paediatric Gastroenterology and Nutrition (ESPGAN) criteria. ${ }^{1415}$ Clinical data were consecutively extracted for the purpose of this study from hospital files and child health centre records. 'Severe gastrointestinal symptoms' between birth and 2 years of age were defined as symptoms causing medical investigation, while 'minor gastrointestinal symptoms' were defined as complaints recalled when taking a careful history but without searching for medical help. 'Signs of malnutrition' at diagnosis included reduced subcutaneous fat, thin extremities, 'empty buttocks' and hanging inguinal and axillar skinfolds. 'Psychological symptoms' included fretful, whimpering behaviour and passivity.

Growth was assessed from the growth chart that follows each child in both countries. Abnormal growth was defined according to criteria set by studies of the national reference populations, ${ }^{16-19}$ approximately corresponding to a rate of weight gain or linear growth less than -2 SD. Attained weight and height at diagnosis was plotted in the Finnish and Swedish growth charts, respectively, and the SD scores were used for further calculations. ${ }^{20}$

Data on infant feeding was available in 10 of the 61 Finnish (no significant difference in age 
at diagnosis between these 10 and the total Finnish patient group) and in 83 (gluten introduction) and 84 (breast feeding) of the 86 Swedish patients.

\section{INFANT FEEDING STUDY GROUPS}

At child health centres healthy 9 or 12 month old children were invited to a study on food ingestion. In Tampere, 107 children (60 at 9 months and 47 at 12 months) were recruited from one child health centre in the city and one in the countryside. In Gothenburg, all 33 children (20 at 9 months and 13 at 12 months) in the catchment area of two selected suburban child health centres, typical of middle and lower class areas, were studied. The study was carried out in 1990-1.

Another group also consisting of 33 children (20 at 9 months and 13 at 12 months) had been studied in Gothenburg in 1978 with the same method for recording of food intake. This group originally served as a control group in another study ${ }^{21}$ and was now used as a historical comparison group.

The recordings were made by the parents, after receiving instruction, and included all foods and beverages given measured with household measures. In Tampere, the recordings were made during the seven days before the child was 9 and 12 months old, respectively. In Gothenburg, they were made during four days around the age of 9 months (range 8-10) and 12 months (range 11-14).

The amount of gluten-containing cereals (wheat, rye, oats, and barley) was calculated by one paediatric dietitian in each centre. The methods applied for calculations were the same in the two study centres and were qualitatively ensured through coordination meetings. For home made foods, estimates of types and amounts of flour used were made from recipes in the most commonly used cookery books in each country and related to tables of energy and nutrient content issued by the National Food Administrations. ${ }^{22} 23$ For industrial products (powder for gruels and porridges),

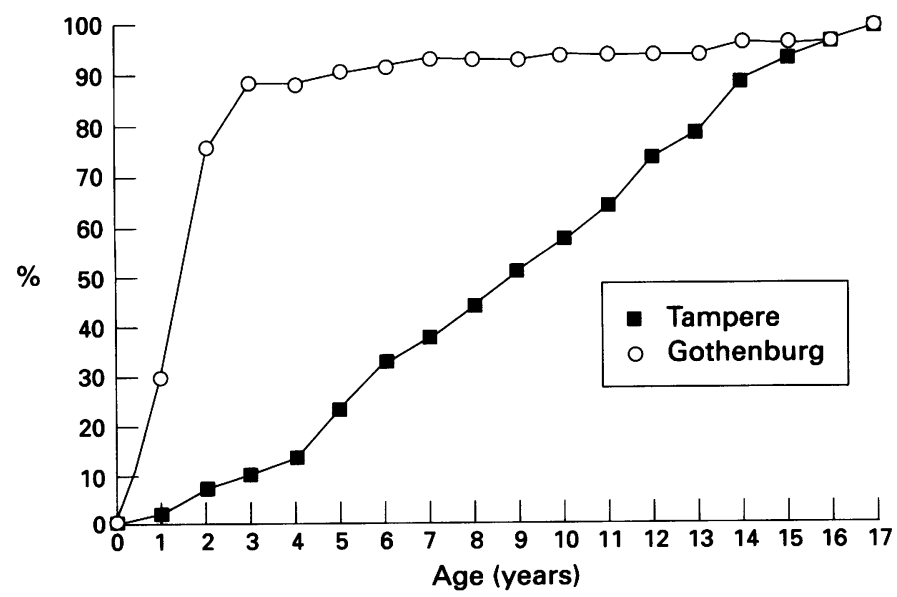

$\begin{array}{lllllllllllllllllll}\text { Tampere } & 1 & 3 & 2 & 2 & 6 & 6 & 3 & 4 & 4 & 4 & 4 & 6 & 3 & 6 & 3 & 2 & 2 & =61\end{array}$ $\begin{array}{lllllllllllllllllll}\text { Gothenburg } & 25 & 40 & 11 & 0 & 2 & 1 & 1 & 0 & 0 & 1 & 0 & 0 & 0 & 2 & 0 & 0 & 3 & =86\end{array}$

Cumulative distribution of age at diagnosis in children with diagnosed coeliac disease by centre. data from the manufacturers were used. The proportions of protein in each type of cereal used in the calculations were, according to the results of cereal analysis from the National Food Administrations in each country, $8.5 \mathrm{~g}$, $8 \cdot 2 \mathrm{~g}, 13.3 \mathrm{~g}$, and $9 \cdot 2 \mathrm{~g}$ per $100 \mathrm{~g}$ of wheat, rye, oats, and barley in Sweden ${ }^{22}$ and $9.9 \mathrm{~g}, 10.0 \mathrm{~g}$, $12.5 \mathrm{~g}$, and $9 \cdot 2 \mathrm{~g}$ in Finland. ${ }^{23}$ The calculations were made separately for each child and the results expressed as amount ingested $/ \mathrm{kg}$ body weight/day.

\section{HLA TYPED GROUPS}

HLA antigens were examined with routine serological methods in 39 Finnish and 61 Swedish children with coeliac disease. Population data from blood donors of each of the two countries were used as a reference.

\section{STATISTICS}

For statistical calculations, the $\chi^{2}$ test, Student's $t$ test, simple regression, Fisher's exact test, Mantel-Haenszel's method for stratified analysis, and odds ratios with $95 \%$ confidence intervals were used where appropriate.

\section{Results}

\section{CLINICAL STUDY}

The age distribution at diagnosis showed considerable differences between the two centres (figure, table 1).

Signs and symptoms at the age of birth to 2 years, irrespective of age at diagnosis, were compared (table 2). The Finnish patients and patients with late diagnosis at both centres had significantly less severe symptoms at this age. The classical presentation was seen in 3\% of the Finnish patients, compared with $79 \%$ of the Swedish children $(p<0.001)$. All of them were diagnosed before 2.5 years of age.

Signs and symptoms at diagnosis differed between the countries and age groups (table 3). When controlling for the different age intervals, significant differences between the countries were found for abdominal distension $(p=0.001)$, constipation $(p<0.05)$, and abnormal weight gain $(p<0.05)$, all more frequent in the Swedish patients. Constipation often appeared in periods, alternating with periods of loose stools/diarrhoea. The group 'other symptoms' comprised menorrhagia with irregular periods $(n=1)$, gastro-oesophageal reflux $(n=1)$, enamel hypoplasia $(n=1)$, and brittle diabetes mellitus $(n=1)$ among the Finnish patients and recurrent fever $(n=3)$, headache $(n=1)$, and exanthema $(n=1)$ among the Swedish patients. Among the Finnish patients, $12(20 \%)$ had insulin dependent diabetes mellitus (IDDM) compared with two $(2 \%)$ among the Swedish.

The mean attained weight at diagnosis was $-0.7 \mathrm{SD}$ scores $(-1.0$ to $-0.4,95 \%$ confidence interval) in the Finnish patients and $-1.4(-1.7$ to $-1 \cdot 2)$ in the Swedish. The mean attained height was $-1.0 \mathrm{SD}$ scores $(-1.3$ to -0.6$)$ in the Finnish and $-0.8(-1.0$ to -0.6$)$ in the Swedish patients. For each age group, there was 
Table 2 Symptoms and growth between birth and 2 years in children with coeliac disease by centre and age at diagnosis; figures in \%

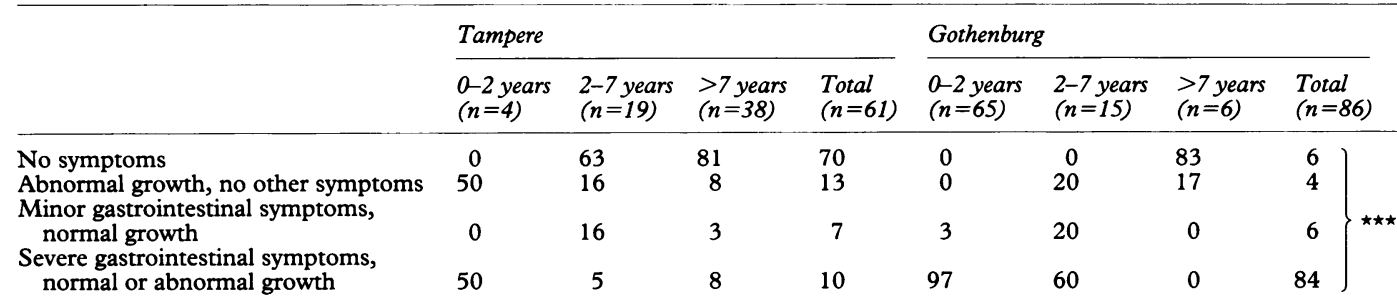

$\star \star \star \mathrm{p}<0.001$ comparing the total between the countries.

Table 3 Signs and symptoms in children with coeliac disease by centre and age at diagnosis; figures in \%

\begin{tabular}{|c|c|c|c|c|c|c|c|c|c|}
\hline \multirow[b]{3}{*}{ No symptoms } & \multicolumn{4}{|l|}{ Tampere } & \multicolumn{5}{|c|}{ Gothenburg } \\
\hline & \multirow{2}{*}{$\begin{array}{c}\begin{array}{c}0-2 \text { years } \\
(n=4)\end{array} \\
0\end{array}$} & \multirow{2}{*}{$\frac{\begin{array}{l}2-7 \text { years } \\
(n=19)\end{array}}{0}$} & \multirow{2}{*}{$\begin{array}{l}\begin{array}{l}7 \text { years } \\
(n=38)\end{array} \\
21\end{array}$} & \multirow{2}{*}{$\begin{array}{l}\begin{array}{l}\text { Total } \\
(n=61)\end{array} \\
13\end{array}$} & \multirow{2}{*}{$\begin{array}{l}\begin{array}{l}0-2 \text { years } \\
(n=65)\end{array} \\
0\end{array}$} & \multirow{2}{*}{$\begin{array}{l}\begin{array}{l}2-7 \text { years } \\
(n=15)\end{array} \\
0\end{array}$} & \multirow{2}{*}{$\begin{array}{l}\begin{array}{l}7 \text { years } \\
(n=6)\end{array} \\
17\end{array}$} & \multicolumn{2}{|c|}{$\begin{array}{l}\text { Total } \\
(n=86)\end{array}$} \\
\hline & & & & & & & & 1 & $\star \star$ \\
\hline $\begin{array}{l}\text { Loose stools/diarrhoea } \\
\text { Abdominal pain } \\
\text { Abdominal distension } \\
\text { Constipation } \\
\text { Vomiting } \\
\text { Signs of malnutrition } \\
\text { Meteorism }\end{array}$ & $\begin{array}{r}25 \\
0 \\
25 \\
25 \\
50\end{array}$ & $\begin{array}{r}42 \\
21 \\
11 \\
5 \\
0\end{array}$ & $\begin{array}{r}29 \\
32 \\
13 \\
3 \\
0\end{array}$ & $\begin{array}{r}33 \\
26 \\
13 \\
5 \\
3 \\
0 \\
3\end{array}$ & $\begin{array}{r}80 \\
8 \\
86 \\
38 \\
48 \\
48 \\
3\end{array}$ & $\begin{array}{l}67 \\
20 \\
67 \\
33 \\
13 \\
20 \\
20\end{array}$ & $\begin{array}{r}33 \\
67 \\
0 \\
17 \\
0 \\
0 \\
17\end{array}$ & $\begin{array}{r}74 \\
14 \\
77 \\
36 \\
38 \\
40 \\
7\end{array}$ & $\begin{array}{l}\star \star \star \\
N S \\
\star \star \star \\
\star \star \star \\
\star \star \star \\
\star \star \star \\
-\end{array}$ \\
\hline $\begin{array}{l}\text { Abnormal linear growth } \\
\text { Abnormal weight gain }\end{array}$ & $\begin{array}{r}100 \\
75\end{array}$ & $\begin{array}{l}58 \\
42\end{array}$ & $\begin{array}{l}45 \\
32\end{array}$ & $\begin{array}{l}52 \\
38\end{array}$ & $\begin{array}{l}48 \\
95\end{array}$ & $\begin{array}{l}33 \\
60\end{array}$ & $\begin{array}{l}33 \\
50\end{array}$ & $\begin{array}{l}44 \\
86\end{array}$ & $\underset{\star \star \star}{N S}$ \\
\hline $\begin{array}{l}\text { Delayed puberty } \\
\text { Psychological/tiredness } \\
\text { Anorexia }\end{array}$ & $\overline{0}$ & $\overline{5}$ & $\overline{0}$ & $\begin{array}{c}15 \dagger \\
2 \\
0\end{array}$ & $\begin{array}{l}5 \overline{7} \\
31\end{array}$ & $\begin{array}{l}-\overline{3} \\
40\end{array}$ & $\begin{array}{l}- \\
33 \\
17\end{array}$ & $\begin{array}{l}40 \dagger \\
51 \\
31\end{array}$ & $\underset{\star \star \star \star}{N S}$ \\
\hline $\begin{array}{l}\text { Anaemia } \\
\text { Iron deficiency } \\
\text { B-12 }\end{array}$ & $\begin{array}{l}0 \\
0\end{array}$ & $\begin{array}{r}11 \\
5\end{array}$ & $\begin{array}{r}16 \\
0\end{array}$ & $\begin{array}{r}13 \\
2\end{array}$ & 0 & 7 & 17 & $\begin{array}{l}2 \\
0\end{array}$ & - \\
\hline $\begin{array}{l}\text { Aplastic } \\
\text { Arthritis/joint pain }\end{array}$ & 0 & 11 & 11 & $\begin{array}{r}0 \\
0 \\
10\end{array}$ & 2 & 0 & 0 & $\begin{array}{l}0 \\
0\end{array}$ & $\overline{-}$ \\
\hline Delayed development/hypotonia & 0 & 5 & 8 & $\begin{array}{l}0 \\
7\end{array}$ & $\begin{array}{l}9 \\
6\end{array}$ & $\begin{array}{l}0 \\
0\end{array}$ & $\begin{array}{r}0 \\
17\end{array}$ & $\begin{array}{l}7 \\
6\end{array}$ & $\overline{-}$ \\
\hline
\end{tabular}

$\dagger=$ Calculated on cases $>13$ years, $n=18$ (Tampere 13 and Gothenburg five).

${ }^{\star} \mathrm{p}<0.05$ comparing the total between the centres; ${ }^{\star \star} \mathrm{p}<0.01 ;{ }^{\star \star \star} \mathrm{p}<0.001 ; \mathrm{NS}=\mathrm{p}>0.05 ;-=$ not tested (too few cases).

Table 4 The amount of protein from different types of gluten-containing cereals eaten by healthy infants; figures are mean (SD) in $\mathrm{g} / \mathrm{kg}$ body weight/day

\begin{tabular}{|c|c|c|c|c|c|c|}
\hline & \multirow[b]{2}{*}{ Wheat } & \multirow[b]{2}{*}{ Rye } & \multirow[b]{2}{*}{ Barley } & \multirow[b]{2}{*}{ Oats } & \multicolumn{2}{|c|}{ Breast feeding } \\
\hline & & & & & $\begin{array}{l}\text { Prevalence } \\
(\%)\end{array}$ & $\begin{array}{l}\text { Frequency } \\
\text { Median (range) }\end{array}$ \\
\hline $\begin{array}{l}9 \text { months } \\
\text { Gothenburg } 1978\end{array}$ & $\underset{\star \star}{0.32}(0.11)$ & $0.03(0.04)$ & $0.001(0.003)$ & $0 \cdot 20(0 \cdot 13)$ & 0 & \\
\hline $\begin{array}{l}\text { Gothenburg } 1990 \\
(n=20)\end{array}$ & $0.48(0.21)$ & $0.04(0.05)$ & $\underset{\star}{0.007}(0.014)$ & $\underset{\star}{0 \cdot 16}(0 \cdot 14)$ & 20 & $2(1-5)$ \\
\hline Tampere 1990 & $0.14(0.09)$ & $0 \cdot 08(0 \cdot 10)$ & $0.03(0.04)$ & $0 \cdot 25(0 \cdot 17)$ & 47 & $4(1-8)$ \\
\hline $\begin{array}{l}12 \text { months } \\
\text { Gothenburg } 1978 \\
(\mathrm{n}=13)\end{array}$ & $0 \cdot 38(0 \cdot 13)$ & $0.04(0.05)$ & 0 & $0.14(0.07)$ & 0 & \\
\hline $\begin{array}{l}\text { Gothenburg } 1990 \\
(n=13)\end{array}$ & $\underset{\star \star \star}{0.42}(0 \cdot 13)$ & $0.09(0.05)$ & $0.02(0.02)$ & $0 \cdot 20(0 \cdot 19)$ & 0 & \\
\hline$\underset{(n=47)}{\text { Tampere } 1990}$ & $0 \cdot 20(0 \cdot 13)$ & $0 \cdot 12(0 \cdot 12)$ & $0.03(0.03)$ & $0.23(0 \cdot 15)$ & 17 & $3(1-5)$ \\
\hline
\end{tabular}

${ }^{\star \star \star} \mathrm{p}<0.001 ;{ }^{\star \star} \mathrm{p}<0.01 ;{ }^{\star} \mathrm{p}<0.05 ;$ no asterisks $=\mathrm{p}>0.05$.

no difference between the two countries. In the whole group, significant correlation was found between age and SD score of attained weight $(r=0.351 ; \mathrm{p}<0.001)$ but not between age and SD score of attained height.

Mean time for exclusive and mixed breast feeding among the coeliac disease patients was $5 \cdot 3(2 \cdot 6$ to $8 \cdot 0)$ and $4 \cdot 3(3 \cdot 7$ to $5 \cdot 0)$ months in Finland and Sweden, respectively. The age at gluten introduction was $5.2(4.9$ to 5.5$)$ and $6.0(5 \cdot 8$ to $6 \cdot 3)$ months.

INFANT FEEDING STUDY

At 9 months of age, the ingestion of wheat protein was more than three times higher in Gothenburg compared with Tampere $(\mathrm{p}<0.001$; table 4$)$ and $50 \%$ higher compared with Gothenburg in $1978(\mathrm{p}<0.01)$. The share of protein originating from industrially produced gruel or porridge out of the total diet was, however, the same, $58 \%$, at both points of time. The ingestion of barley and oats protein showed small but statistically significant differences between the countries.

At 12 months of age, the children in Gothenburg ingested double the amount of wheat protein compared with the children in Tampere $(p<0.001$; table 4$)$ and $10 \%$ more than in 1978; this was not significant. The ingestion of rye and barley protein showed small but statistically significant differences 
Table 5 Occurrence of different HLA types in children with coeliac disease and the reference group by country; figures in \%

\begin{tabular}{|c|c|c|c|c|c|c|c|c|}
\hline \multirow[b]{2}{*}{$H L A$} & \multicolumn{4}{|l|}{ Finland } & \multicolumn{4}{|l|}{ Sweden } \\
\hline & $\begin{array}{l}\text { Coeliac } \\
\text { disease } \\
(n=39)\end{array}$ & $\begin{array}{l}\text { Reference } \\
\text { group } \\
(n=900)\end{array}$ & $\begin{array}{l}\text { Odds } \\
\text { ratio }\end{array}$ & $\begin{array}{l}(95 \% \\
\text { confidence } \\
\text { interval) }\end{array}$ & $\begin{array}{l}\text { Coeliac } \\
\text { disease } \\
(n=61)\end{array}$ & $\begin{array}{l}\text { Reference } \\
\text { group } \\
(n=1244)\end{array}$ & $\begin{array}{l}\text { Odds } \\
\text { ratio }\end{array}$ & $\begin{array}{l}(95 \% \\
\text { confidence } \\
\text { interval) }\end{array}$ \\
\hline Al & 44 & 20 & 3.09 & $(1.53$ to 6.21$)$ & 57 & 26 & 3.59 & $(2.07$ to 6.24$)$ \\
\hline B7 & 15 & 24 & 0.58 & $(0.19$ to 1.42$)$ & 13 & 28 & 0.33 & $(0.13$ to 0.75$)$ \\
\hline B8 & 82 & 20 & $18 \cdot 29$ & (7.73 to $49 \cdot 69)$ & 66 & 25 & $5 \cdot 71$ & $(3.22$ to 10.20$)$ \\
\hline B35 & 10 & 27 & 0.31 & $(0.08$ to 0.88$)$ & 5 & 13 & 0.35 & $(0.07$ to 1.09$)$ \\
\hline DR1 & 5 & 36 & $0 \cdot 10$ & $(0.01$ to 0.38$)$ & 11 & $19^{\star}$ & 0.56 & $(0.20$ to 1.34$)$ \\
\hline DR3 & 95 & 23 & 61.93 & $(15.68$ to 532.47$)$ & 92 & $26^{\star}$ & $32 \cdot 0$ & $(12.0$ to 106$)$ \\
\hline DR4 & 13 & 29 & 0.36 & $(0.12$ to 0.98$)$ & 7 & $34^{\star}$ & $0 \cdot 14$ & $(0.03$ to 0.39$)$ \\
\hline DR7 & 21 & 15 & $1 \cdot 46$ & $(0.61$ to 3.41$)$ & 23 & $20^{\star}$ & $1 \cdot 18$ & (0.57 to 2.42$)$ \\
\hline DR8 & 8 & 15 & 0.47 & $(0.09$ to 1.53$)$ & 8 & $14^{\star}$ & 0.55 & $(0.16$ to 1.51$)$ \\
\hline
\end{tabular}

over time in Gothenburg. The amount of protein from industrially produced gruel or porridge was $52 \%$ in 1978 and $44 \%$ in 1990 .

The recorded breast feeding prevalence at 9 months was significantly higher in Tampere than in Gothenburg $(p<0.05)$, where the breast feeding prevalence had in turn increased significantly compared with 1978 ( $p<0.05$; table 4 ). At 12 months, $17 \%$ of the Tampere children were still partially breast fed, compared with none of the Gothenburg children $(p>0.05)$.

\section{HLA TYPING}

The HLA comparison revealed that the HLA haplotypes A1, B8, DR3 dominated among those with coeliac disease at both centres (table 5) with no significant differences between the groups.

In Tampere a significantly lower frequency of HLA haplotypes B35, DR1, and DR4 was found in those with coeliac disease compared with the Finnish reference, while B7 and DR4 were significantly less frequent among those with coeliac disease in Gothenburg compared with the Swedish reference group (table 5).

\section{Discussion}

This joint study, comparing coeliac disease between two centres in the neighbouring countries Finland and Sweden, was carried out as a result of the previously described different trends of the disease. ${ }^{1011}$ The study consists of three different parts in order to explore possible causes and associated factors that could explain the differences.

In the first part, a study of clinical expression and age distribution, significant differences in the clinical presentation were confirmed. While the majority of patients in Tampere, Finland were diagnosed after 8 years of age, presenting with mild and diffuse symptoms, the majority of patients in Gothenburg, Sweden were diagnosed before 2 years of age and had the classical and more severe presentation. The higher rate of IDDM in Finnish patients is mainly due to different screening procedures: in Finland, children with IDDM were serologically screened for coeliac disease each year, in Sweden only once. The mild symptoms during the first two years of life among the Finnish patients with late diagnosis indicate that the clinical differences cannot be explained by missed diagnosis during early infancy in Tampere.

While data on growth were routinely measured prospectively and depicted in growth charts, data on signs and symptoms relied on retrospective data, as recorded in documents. The risk of a systematic bias, especially when comparing two countries, must be considered. However, the health care systems in Finland and Sweden are very similar, as are also the general medical standards and practices. Further, the observed clinical differences are so huge, that it is highly unlikely they could be explained only as a bias effect.

What factors could then be associated with the differences in clinical expression and incidence? Family, twin, and HLA studies have all shown the existence of a genetic factor of importance for development of coeliac disease. ${ }^{24}$ Could this factor explain the differences?

In the second part of the study, a predominance of the HLA haplotypes A1, B8, DR3 were seen in patients in both study areas, with no significant difference between the case groups. These HLA groups were more common in the Swedish than in the Finnish reference group, and may be one determinant of the higher incidence/prevalence of coeliac disease in Sweden. Given the similar HLA set up in those with coeliac disease in both Sweden and Finland, it is unlikely that genetic differences explain the rapid change in clinical expression and increased incidence observed.

A factor more likely to contribute to such changes is the infant feeding pattern. We therefore compared food ingestion between groups of healthy infants. Patients with coeliac disease often have anorexia as a dominant feature and retrospective food recall of coeliac disease patients from the time before the development of symptoms might be less valid and perhaps biased. Records of food ingestion have been found to be a valid method, and one, three, and seven day records have shown equivalent results. ${ }^{25}$

The duration of breast feeding in both Finland and Sweden was very short in the early 1970s. Since then it has increased continuously, both in the population and among infants who develop coeliac disease later. ${ }^{1} 101326$ In Finland this coincided with the trend of later manifestations of symptoms among coeliacs. In Sweden, surprisingly, this was followed by, or coincided with, the strong increase in coeliac 
disease incidence. The most recent population figures indicate a breast feeding prevalence of $60-70 \%$ at 6 months in Finland and $50 \%$ in Sweden. In this study, we found a significantly higher prevalence of breast feeding in Tampere in 9 month old infants compared with Gothenburg. The conclusion from a series of Italian studies was that extended breast feeding delays the development of clinical symptoms of coeliac disease. ${ }^{27-29}$ However, the divergent trends of Finland and Sweden indicate that factors other than breast feeding also influence the result.

The method for calculation of ingested cereal protein used in this study avoids the controversial question of toxicity of prolamines and the pertaining methodological issues. ${ }^{30} \mathrm{It}$ also allows comparison between groups as there is a strong correlation between the amounts of protein and prolamine in cereals.

In Finland, the recommended age for gluten introduction has been 5 months since before 1970. In Sweden, it was changed from 4 to 6 months in 1983, and that recommendation was closely followed. The patients with coeliac disease did not differ in this aspect and although we had data on gluten introduction on only a fraction of the Finnish patients, previous studies have shown the same. ${ }^{113}$ Also in 1983, the amount of gluten in the industrially produced gruels and porridges in Sweden was doubled on average. ${ }^{13}$

Infants in Gothenburg ingested two to three times more wheat protein than in Tampere. At 9 months of age they also consumed $50 \%$ more than in 1978, which was before the onset of the increase of incidence.

Some statistically significant differences of the amounts of rye, barley, and oats protein consumed between the countries and over time were found, although so small that they are probably without clinical importance.

In this study, we have used all accessible material to compare possible background factors of importance for the different development of coeliac disease. Although the design of our study does not permit firm conclusions, it indicates that the amount of wheat protein consumed in infancy might be one factor of importance for the clinical expression of coeliac disease. What does that imply? One possibility is that the ingestion of high amounts of wheat protein in infancy might lead to more obvious symptoms in children with a 'flat mucosa' who otherwise may have remained undiagnosed. If that is the case, children born in Sweden after 1982-3 would be at less risk of diffuse and prolonged morbidity, which is typical of coeliac disease undiagnosed until adulthood. ${ }^{31}$ The concomitant risk of malignancies may thus also be avoided. ${ }^{32}$ The high prevalence of 'silent' coeliac disease among Swedish blood donors, ${ }^{33}$ close to the present cumulative incidence among Swedish children, might support this hypothesis.

On the other hand, the higher ingestion of wheat protein during infancy might lead to the clinical expression of coeliac disease and development of a flat mucosa in a group of people with genetic susceptibility for the disease who, on lower exposure, may remain completely healthy with a normal or almost normal intestinal mucosa. The answer to this question, however, lies beyond the scope of this study.

The study was supported by grants from Emil Aaltonen Foundation, Finland and The Academy of Finland, and The Göteborg Medical Society, the University of Gothenburg, the First of May Flower Annual Campaign for Children's Health, and the Wilhelm and Martina Lundgren Foundation in Sweden. We wish to express our special thanks to the parents and the staff at the child health centres who provided us with food records, to Ingrid Odenman and Maria-Liisa Lauhkonen, paediatric dietitians who skilfully carried out the calculations paediatric dietitians who skilfully carried out the calculations on the infant feeding, and to Saija Koskimies, Finnish Red Cross Blood Transfusion Service, Tissue Typing Laboratory, Helsinki
and Lena Sandberg, The Regional Blood Centre, Sahlgrenska Hospital, Göteborg, who performed the HLA typing.

1 Mäki $\mathrm{M}$, Kallonen $\mathrm{K}$, Lähdeaho $\mathrm{ML}$, Visakorpi JK. Changing pattern of childhood coeliac disease in Finland. Acta Paediatr Scand 1988; 77: 408-12.

2 Berg NO, Lindberg T. Incidence of coeliac disease and transient gluten intolerance in children in a Swedish urban community. Acta Paediatr Scand 1979; 68: urban com $397-400$.

3 Littlewood JM, Crollick AJ, Richards I. Childhood coeliac disease is disappearing. Lancet 1980; ii: 1359.

4 Challacombe DN, Baylis JM. Childhood coeliac disease is disappearing. Lancet 1980; ii: 1360.

5 Dossetor J, Gibson A, McNeish A. Childhood coeliac disease is disappearing. Lancet 1981 ; i: $322-3$.

6 Logan R, Rifkind EA, Busuttil A, Gilmour HM, Ferguson A. Prevalence and 'incidence' of celiac disease in Edinburgh and the Lothian region of Scotland. Gastroenterology 1986; 90: 334-42.

7 Stevens FM, Egan MB, Cryan E, McCarthy CF, McNicholl B. Decreasing incidence of coeliac disease. Arch Dis Child 1987; 62: 465-8.

8 Rossipal E. The incidence of childhood coeliac disease in Austria: a study covering the period 1969-86. In: Kumar PJ, Walker-Smith JA, eds. Coeliac disease: 100 years. Leeds: Leeds University Press, 1991: 299-302.

9 Greco L, Tozzi AE, Mayer M, Grimaldi M, Silano G, Auricchio S. Unchanging clinical picture of coeliac disease presentation in Campania, Italy. Eur $f$ Pediatr 1989; 148: $610^{-3}$

10 Mäki M, Holm K. Incidence and prevalence of coeliac disease in Tampere. Coeliac disease is not disappearing. Acta Paediatr Scand 1990; 79: 980-2.

11 Ascher H, Krantz I, Kristiansson B. Increasing incidence of coeliac disease in Sweden. Arch Dis Child 1991; 66: 608-11.

12 Cavell B, Stenhammar L, Ascher $\mathrm{H}$, et al. Increasing incidence of childhood coeliac disease in Sweden. Results of a national study. Acta Paediatr 1992; 81: 589-92.

13 Kristiansson B, Ascher H, Odenman I, Sandberg L. The incidence of coeliac disease and changes in gluten consumption. In: Mearin ML, Mulder CJ, eds. Coeliac disease. Dordrecht: Kluwer Academic Publishers, 1991: 107-14.

14 Meeuwisse GW. Diagnostic criteria in coeliac disease. Acta Paediatr Scand 1970; 59: 461-3.

15 Revised criteria for diagnosis of coeliac disease. Report of Working Group of European Society of Paediatric Gastroenterology and Nutrition. Arch Dis Child 1990; 65: 909-11.

16 Sorva R, Tolppanen E-M, Perheentupa J. Variation of growth in length and weight of children. I. Years 1 and 2 . Acta Paediatr Scand 1990; 79: 490-7.

17 Sorva R, Lankinen S, Tolppanen E-M, Perheentupa J. Variation of growth in length and weight of children. II. After infancy. Acta Paediatr Scand 1990; 79: 498-506.

18 Karlberg J. On the construction of the infancy-childhoodpuberty growth standard. Acta Paediatr Scand 1989; 356 (suppl): 26-37.

19 Kristiansson B. The growth curve in diagnosis and treatment of children of pre-school age. Nord Med 1987; 102: $272-5$.

20 Karlberg P, Taranger J. The somatic development of children in a Swedish urban community. Acta Paediatr Scand ren in a Swedish urban com
$1976 ; 258$ (suppl): $1-148$.

21 Kristiansson B. Low rate of weight gain in infancy and early childhood. A clinical prospective study. Göteborg: University of Gothenburg, 1980. [Dissertation.]

22 Swedish National Food Administration. Food composition tables. Stockholm: Liber, 1986

23 Rastas M, Seppänen R, Knuts L-R, Karvetti R-L, Varo P. Nutrient composition of foods. Hämeenlinna: Karisto $\mathrm{Oy}$, 1989

24 Kagnoff $M$. Role of environmental and genetic factors in celiac disease. In: Branski $\mathrm{D}$, Rozen $\mathrm{P}$, Kagnoff $\mathrm{M}$, eds. Gluten-sensitive enteropathy. Basel: Kargel, 1992: 15-28.

25 Persson L-Â, Carlgren G. Measuring children's diets Evaluation of dietary assessment techniques in infancy
and childhood. Int $\mathcal{f}$ Epidemiol 1984; 13: 506-17.

26 Lindberg T. Coeliac disease and infant feeding practices. Lancet 1981; i: 449.

27 Auricchio S, Follo D, de Ritis G, et al. Does breast feeding protect against the development of clinical symptoms of
uricchio $\mathrm{S}$, Follo $\mathrm{D}$, de Ritis $\mathrm{G}$, et al. Does breast feeding 
celiac disease in children? $f$ Pediatr Gastroenterol Nutr 1983; 2: 428-33.

28 Greco L, Mayer M, Grimaldi M, Follo D, De Ritis G, Auricchio $S$. The effect of early feeding on the onset of symptoms in celiac disease. $\mathcal{F}$ Pediatr Gastroenterol Nutr 1985; 4: 52-5

29 Greco L, Auricchio S, Mayer M, Grimaldi M. Case control study on nutritional risk factors in celiac disease. $\mathcal{F}$ Pediatr Gastroenterol Nutr 1988; 7: 395-9.

30 Shewry P, Tatham A, Kasarda D. Cereal proteins and coeliac disease. In: Marsh $M$, ed. Coeliac disease.
Oxford: Blackwell Scientific Publications, 1992: 30148

31 Collin P, Hällström O, Mäki M, Viander M, Keyriläinen O. Atypical coeliac disease found with serologic screening. Scand $\mathcal{F}$ Gastroenterol 1990; 25: 245-50.

32 Holmes GK, Prior P, Lane MR, Pope D, Allan RN. Malignancy in coeliac disease - effect of a gluten free diet. Gut 1989; 30: 333-8.

33 Grodzinsky E, Franzen L, Hed J, Ström M. High prevalence of celiac disease in healthy adults revealed by antigliadin antibodies. Ann Allergy 1992; 69: 66-70.

\section{Experimental glomerulonephritis - a decorous approach to} treatment

The most important factor leading to progressive renal damage in glomerulonephritis is the accumulation of extracellular matrix which can be measured in histological sections by fluorescent antibody staining for fibronectin. The excess matrix accumulates because of overactivity of transforming growth factor-beta (TGF- $\beta$ ) which, after tissue injury, is released initially from degranulating platelets and this then leads to autoinduction of $\mathrm{TGF}_{-\beta}$ production by local tissue cells. It seems possible, therefore, that progressive damage might be prevented by the inhibition of TGF- $\beta$.

There are three isoforms of $\mathrm{TGF}_{-\beta}: \mathrm{TGF}_{-\beta 1}, \mathrm{TGF}_{-\beta 2}$, and $\mathrm{TGF}_{-\beta 3}$. An anti-TGF- ${ }_{-\beta 1}$ antibody given to glomerulonephritic rats has been shown to inhibit matrix production in the glomeruli. One of the effects of $\mathrm{TGF}_{-\beta}$ is to induce the production in the tissues of a proteoglycan molecule called decorin. This in turn neutralises $\mathrm{TGF}_{-\beta}$ and, unlike the isoform specific antibody, it affects all three isoforms.

Workers in Utah and California (Wayne A Border and colleagues, Nature 1992; 360: 361-4) have given intravenous decorin to rats with antithymocyte serum induced glomerulonephritis. After the injection of antithymocyte serum the rats were given either no decorin or daily intravenous injections of either bovinte or recombinant human decorin for two, four, or six days. The animals were killed after seven days and the amount of fibronectin deposited in their glomeruli was quantified. Those given no decorin or treated for only two days had uniformly high concentrations of fibronectin deposition but the rats treated for four or six days had much lower concentrations, which approached those found in normal controls. When glomerular deposition of other matrix components thought to be specifically induced by $\mathrm{TGF}_{-\beta}$ was measured the results were very similar. Urinary protein excretion on day 7 after the antithymocyte serum was also reduced if the rats had been given decorin for four or six days. Urine protein to creatinine ratios were 0.7 in normal rats, 15.2 in glomerulonephritic rats given no decorin, 14.8 in those given decorin for two days, and 2.4 in those given it for four or six days $(p=0.01$ for four or six days decorin compared with no decorin).

Radiolabelled decorin given intravenously accumulates in the kidneys, liver and lungs and the authors suggest, therefore, that it may prove useful in the treatment of proliferative diseases in these three organs. The different isoforms of $\mathrm{TGF}_{-\beta}$ may be implicated in different diseases, for instance $\mathrm{TGF}_{-\beta 1}$ is raised in glomerulonephritis and $\mathrm{TGF}_{-\beta 2}$ in the eye in proliferative vitreoretinopathy and in the skin in systemic sclerosis. The availability of human recombinant decorin should make problems with immunogenicity less likely.

Clearly, from rat to human disease is a large step and the possibility of undesired effects especially in growing and developing organs must be explored but perhaps we can hope that work along these lines may point towards treatment of hitherto untreatable diseases. 